\title{
Preterm baby with gastric pneumatosis: a new association with a desirable outcome
}

\author{
Zahreddin Guma Abusalah, Jennifer George
}

Neonatal Intensive Care Unit, Mediclinic City Hospital, Dubai, United Arab Emirates

\section{Correspondence to} Dr Zahreddin Guma Abusalah, zahreddin.abusalah@mediclinic. ae

Accepted 15 April 2019

\section{DESCRIPTION}

A preterm female baby was delivered by caesarean section at 29 weeks of gestation. Apgar scores were 7 at $1 \mathrm{~min}$ and 9 at $5 \mathrm{~min}$. Her birth weight was $0.890 \mathrm{~kg}(<9$ th centile). She was on humidified heated high flow nasal cannula (HHHFNC) therapy for the first 3 days of life. On day 4, enteral feeding was initiated. However, she developed bilious vomiting and abdominal distension. Abdominal radiograph was strongly suggestive of intestinal obstruction with double bubble appearance. She was electively intubated and ventilated for surgical management. Laparotomy revealed multiple atresias of the jejunum. Three jejunojejunal anastomoses were performed. She was successfully extubated after 5 days of mechanical ventilation. She received HHHFNC therapy for further 3 days.

After 3 weeks, enteral feeding was commenced. Once more, she developed abdominal distension. Upper gastrointestinal contrast study revealed intestinal obstruction. Severe stenosis at the most distal jejunal anastomosis was identified. Resection and anastomosis were performed. Another 2 days

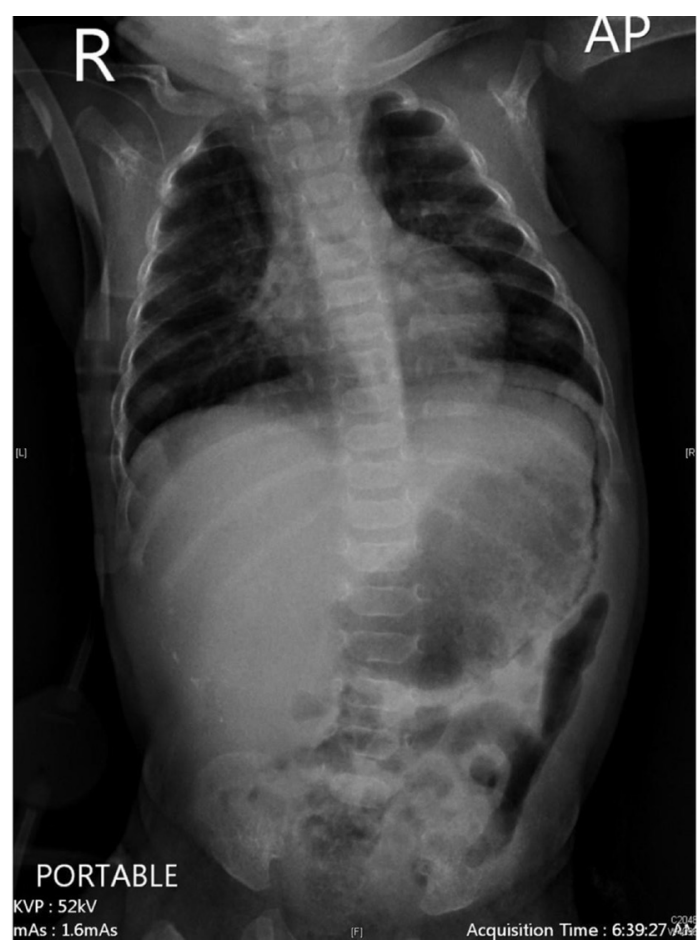

Figure 1 Chest and abdomen X-ray showing a rim of intramural gas in the wall of the stomach, that is, consistent with gastric pneumatosis. No radiological features of necrotising enterocolitis could be seen in the intestine.

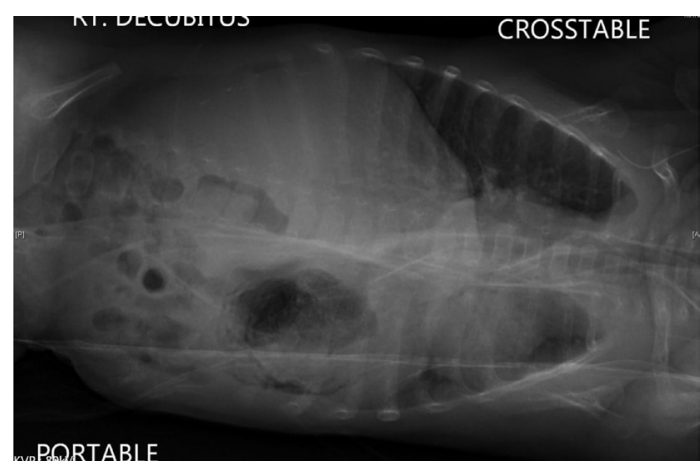

Figure 2 Lateral decubitus abdomen X-ray demonstrating the gastric pneumatosis. No evidence of free air excluding gastric or associated bowel perforation.

of elective mechanical ventilation were required for the second surgery. HHHFNC was required for 4 more days.

Ten days postoperatively, enteral feeds were introduced. Full bottle feeding was established over the subsequent 2 weeks.

At the age of 50 days, she developed several episodes of vomiting associated with abdominal distension. Abdominal radiograph (figures 1 and 2) showed isolated gastric pneumatosis (GP). Abdominal ultrasound scan did not show any evidence of pyloric stenosis. Her $\mathrm{C}$ reactive protein was slightly raised at $14.2 \mathrm{mg} / \mathrm{L}$. The platelets count was normal, and her blood culture result showed no growth. She had to receive HHHFNC at $4 \mathrm{~L} /$ min for 24 hours as part of the supportive care management. Enteral feeds were suspended for 5 days. A course of broad spectrum triple intravenous antibiotic therapy was administered for the same

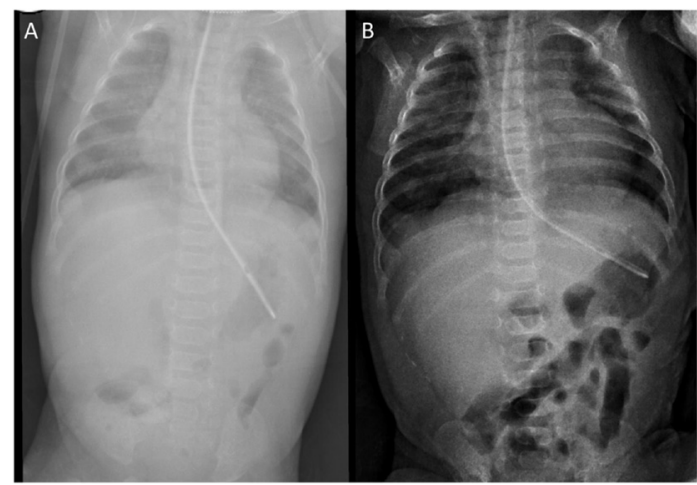

Figure 3 (A) Chest and abdomen X-ray performed after 24 hours with radiological resolution of the condition.

(B) Repeat chest and abdomen X-ray after 72 hours confirming permanent resolution of gastric pneumatosis. 
duration. The radiological finding of GP has resolved on repeat abdominal X-ray, 24 and 72 hours later (figure 3A,B). Milk feeds were restarted and increased until full feeds over a period of 2 days.

Three weeks later, she was discharged from the hospital in good condition weighing $1.740 \mathrm{~kg}$.

Several conditions were reported to be associated with GP. ${ }^{1-4}$ None of the previously reported conditions was encountered in the case of this baby. She has never received nasal positive pressure ventilation. She was fully bottle fed when GP has developed. Her echocardiography was normal and she has never received steroids, indomethacin or ibuprofen. There were no clinical and radiological features of necrotising enterocolitis.

\section{Learning points}

Jejunal atresia is a new association with GA in neonates.

- Gastric pneumatosis may present well after the relief of the intestinal obstruction.

- The condition may follow a benign course with excellent outcome. The management strategy of necrotising enterocolitis is not strictly required. ${ }^{4}$
The development of Gastric Pneumatosis (GA) with jejunal atresia has never been previously reported.

The course and outcome of GA appears to be largely determined by these associations. ${ }^{45}$

Contributors JG drafted the initial and approved the final manuscript. ZGA revised the initial and wrote the final manuscript; prepared the images; followed the patient. ZGA and JG and treated the patient.

Funding The authors have not declared a specific grant for this research from any funding agency in the public, commercial or not-for-profit sectors.

Competing interests None declared.

Patient consent for publication Obtained.

Provenance and peer review Not commissioned; externally peer reviewed.

\section{REFERENCES}

1 Markel TA, Wanner MR, Billmire DF. Gastric pneumatosis secondary to pyloric stenosis. $J$ Pediatr Surg 2013;48:655-7.

2 Penninga L, Werz MJ, Reurings JC, et al. Gastric pneumatosis in a small-for-gestationalage neonate. BMJ Case Rep 2015;2015:bcr2014208390.

3 Brady A-C, Dillon PA. Gastric pneumatosis. N Eng/ J Med Overseas Ed 2015;373:954.

4 Chew SJ, Victor RS, Gopagondanahalli KR, et al. Pneumatosis intestinalis in a preterm infant: should we treat all intestinal pneumatosis as necrotising enterocolitis? BMJ Case Rep 2018;2018:bcr-2018-224356.

5 Mahgoub L, Lilic N, Evans M, et al. Stomach infarction in an ex-premature infant. BMJ Case Rep 2014;2014:bcr2013202814

Copyright 2019 BMJ Publishing Group. All rights reserved. For permission to reuse any of this content visit https://www.bmj.com/company/products-services/rights-and-licensing/permissions/

BMJ Case Report Fellows may re-use this article for personal use and teaching without any further permission.

Become a Fellow of BMJ Case Reports today and you can:

- Submit as many cases as you like

- Enjoy fast sympathetic peer review and rapid publication of accepted articles

- Access all the published articles

- Re-use any of the published material for personal use and teaching without further permission

For information on Institutional Fellowships contact consortiasales@bmjgroup.com

Visit casereports.bmj.com for more articles like this and to become a Fellow 